\title{
A New Methodology For Developing The MIS Master Plan
}

\author{
Mohammad Dadashzadeh, Ph.D., Oakland University, USA
}

\begin{abstract}
Organizations, small and large, for profit and non-profit, service oriented as well as manufacturing, have continued to increase their expenditures in information technology (IT) in recent years throughout the world. These expenditures in manufacturing floor and office workflow automation, $P C$ 's, application packages, customized software development, communications and wireless networking, the Internet, and web-based applications, have been intended to be investments for improving efficiency, increasing effectiveness, and maintaining or advancing competitive position. Unfortunately, not all investments in IT have brought the anticipated payoff. This fact, combined with the rapid pace of change in IT leading to quick obsolescence of hardware and software platforms, have renewed attention to long term planning for IT investments. This paper presents an input/output model for developing a Management Information Systems (MIS) Master Plan and compares several methodologies, including IBM's Business Systems Planning and the Information Engineering approach, for developing such a plan. Moreover, we present a new methodology for IT planning that seeks to overcome the shortcomings of the existing methodologies while building on their strengths.
\end{abstract}

Keywords: Strategic Planning, Information Systems, IT Planning, MIS Master Plan, Business Systems Planning, Critical Success Factors, Information Engineering, Information Architecture

\section{WHY PLAN FOR IT?}

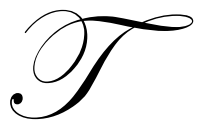

oday, it is hard to find an organization that is not spending for information technology in one form or another. Whether it is IT to support business transaction processing or it is IT to support business communication, organizations have become extremely dependent on IT. Indeed, imagining a business world without mobile communication or e-mail is an increasingly difficult task. At the same time, the rapid pace of change in IT leading to quick obsolescence of hardware and software platforms, have renewed attention to long term planning for IT investments.

Strategic planning for IT is necessary for the following reasons:

- $\quad$ You cannot build it overnight!

- $\quad$ There is no complete turnkey solution.

- $\quad$ No solution is final! Organizations evolve. So should the IT supporting the organization.

- In many cases, decisions we make today impact the organization's technology infrastructure for the next 5+ years.

As such, any attempt at developing a long term IT plan must address the needed flexibility to evolve while defining an architectural framework that is aligned with the strategic focus of the organization.

Figure 1 depicts a widely accepted notion of the Information Architecture that should frame IT planning results [2]. The foundational pieces of the architecture call for planning for development and maintenance of a data integration infrastructure (data, e.g., customer information, being stored once and made accessible to all applications needing it) and a communication integration infrastructure (access to needed data from any Internet connected device 
subject to security and full access rights considerations). The application portfolio recognized for development and maintenance by the long term IT planning include: Transaction Processing Systems (TPS), Management Reporting Systems (MRS), Executive Information Systems (EIS), Decision Support Systems (DSS), Knowledge Management Systems (KMS), Workflow Information Systems (WIS), and Inter-Organizational Systems (IOS) such as business-tobusiness commerce. The Information Architecture framework acknowledges the importance of prioritized and balanced application portfolio development. In particular, although transaction processing systems encompass the largest share of application categories (as reflected by the size of the TPS rectangle in Figure 1), balanced development addresses the common pitfall of concentrating on completing TPS before turning attention to the more difficult systems, such as DSS.

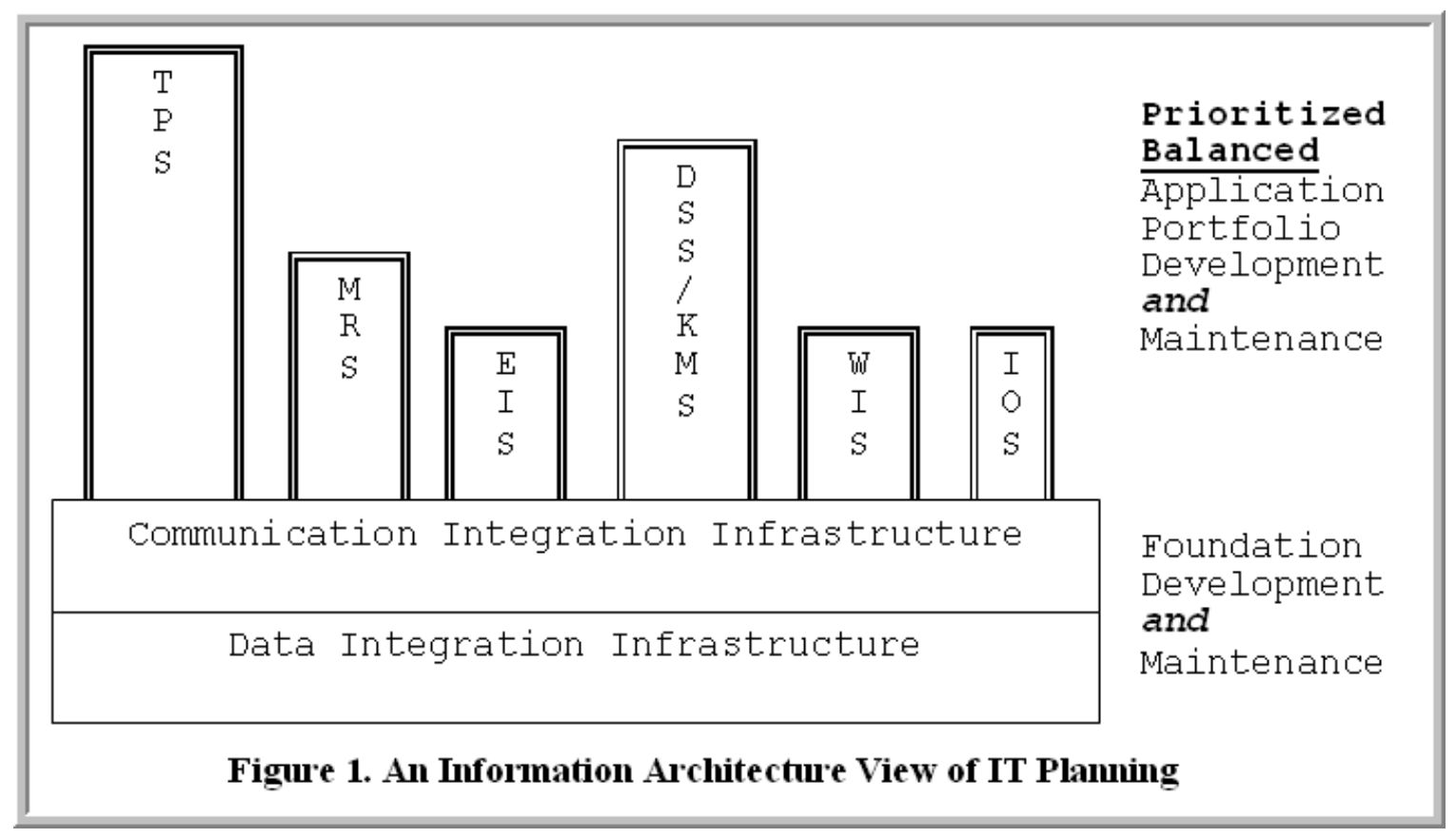

Although there is general agreement on the architectural view of IT planning results, there are a number of methodologies for the process of IT planning. In this paper, we examine the strengths and weaknesses of the prominent methodologies and propose a new methodology that seeks to overcome those shortcomings while building on the strengths.

\section{AN INPUT/OUTPUT VIEW OF IT PLANNING}

Any strategic IT planning methodology can be considered as a process taking certain inputs and producing certain outputs $[8,11,12,18,20,23]$. This black box approach is a useful first step in comparing different methodologies. Based on the Information Architecture view of IT planning in previous section, Figure 2 presents our input/output model for IT planning.

As depicted in the model, the MIS Master Plan (i.e., the output of any IT planning process) must address the following items:

1. $\quad$ MIS Policies, Strategies, and Objectives

2. Organizational Information Requirements

3. Application Portfolio 
4. Project Ranking

5. Multi-Year Implementation Schedule

In turn, the inputs to the IT planning process would include:

1) Business Strategic Plan

a. Desired Future Positions

b. Strategic Focus of MIS

2) Current IT Capabilities

3) Emerging Technologies

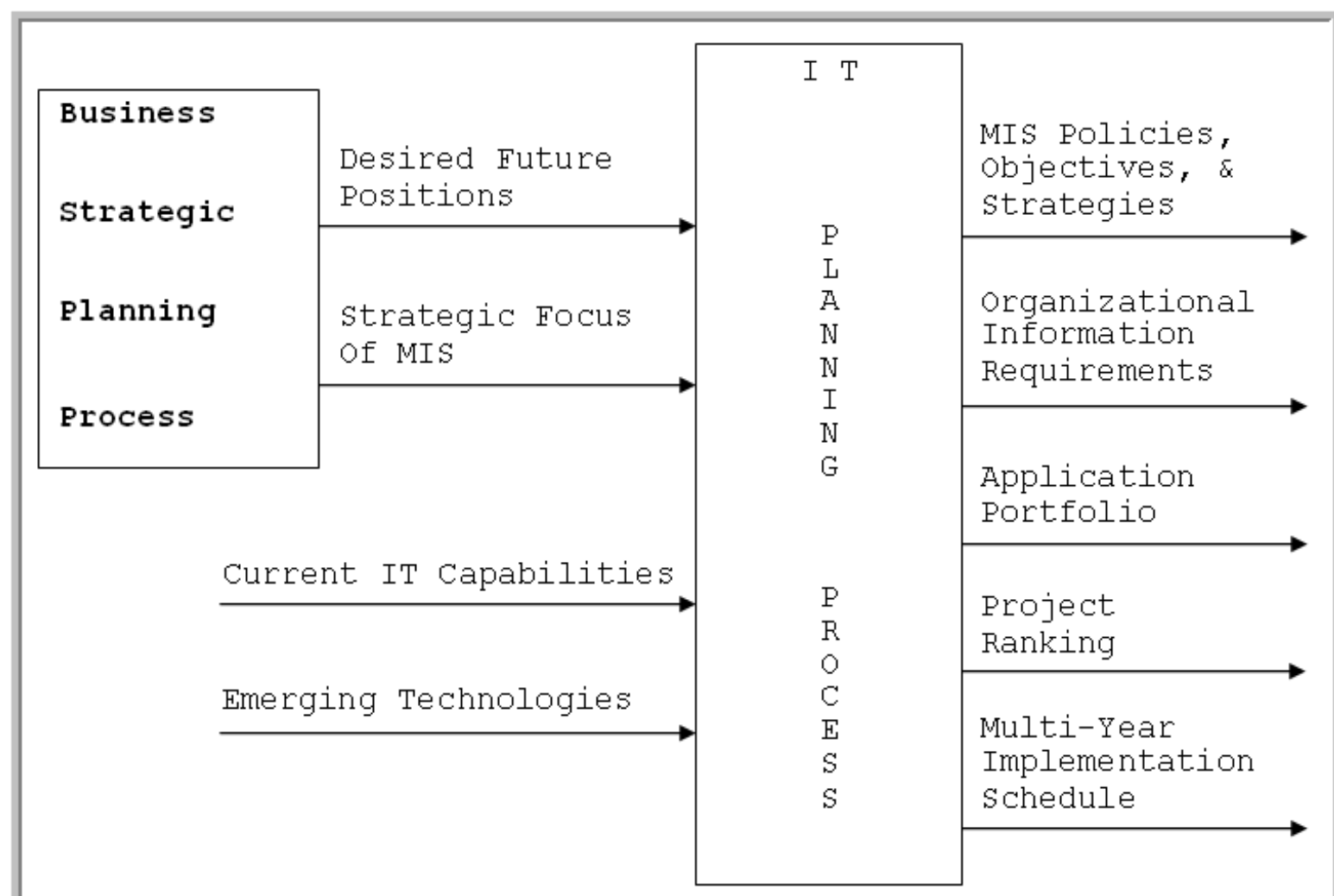

Figure 2. An Input/Output Model of IT Planning

Although there is considerable agreement on the outputs of the IT planning process (i.e., the table of contents of the MIS Master Plan), existing methodologies differ in both the extent of detail produced in the output as well as the formality of the required inputs. In addition, of course, each methodology brings its own "procedure" for conducting the process. The next section examines the highlights of three prominent methodologies for IT planning.

\section{EXISTING METHODOLOGIES FOR IT PLANNING}

As indicated, any IT planning process/methodology must address: organizational (enterprise-wide) information requirements, applications to make use of that information, and managerial agreement on the investment priorities. Existing methodologies, while agreeing on this basic premise, differ in the formality of the required inputs, 
the procedures for arriving at the required outputs, and the extent of detail in the produced output. Table 1 lists the three prominent methodologies that we examine in this section.

Table 1. Existing Methodologies for IT Planning

\begin{tabular}{|l|l|l|}
\hline \multicolumn{1}{|c|}{ Methodology } & \multicolumn{1}{|c|}{ Synopsis } & \multicolumn{1}{c|}{ Developer } \\
\hline Business Systems Planning (BSP) & $\begin{array}{l}\text { Developing an integrated data architecture to } \\
\text { support application portfolio implementation. }\end{array}$ & IBM \\
\hline Critical Success Factors (CSF) & Identifying the right information for managers. & John Rockart \\
\hline $\begin{array}{l}\text { Information Engineering/ } \\
\text { Information Strategy Planning (ISP) }\end{array}$ & $\begin{array}{l}\text { Developing an information architecture to support } \\
\text { application portfolio implementation. }\end{array}$ & James Martin \\
\hline
\end{tabular}

\subsection{Business Systems Planning}

Figure 3 depicts the top-down planning with bottom up implementation that represents IBM's Business Systems Planning methodology [10]. BSP is a comprehensive approach to documenting the exiting business processes and inventory of applications in support of them. The goal is to arrive at a detailed conceptual model of (entity-relationship diagram, ERD) an enterprise-wide integrated database before starting to implement/re-design the integrated application portfolio needed in support of those processes. Table 2 summarizes the advantages and limitations of IBM's BSP methodology.

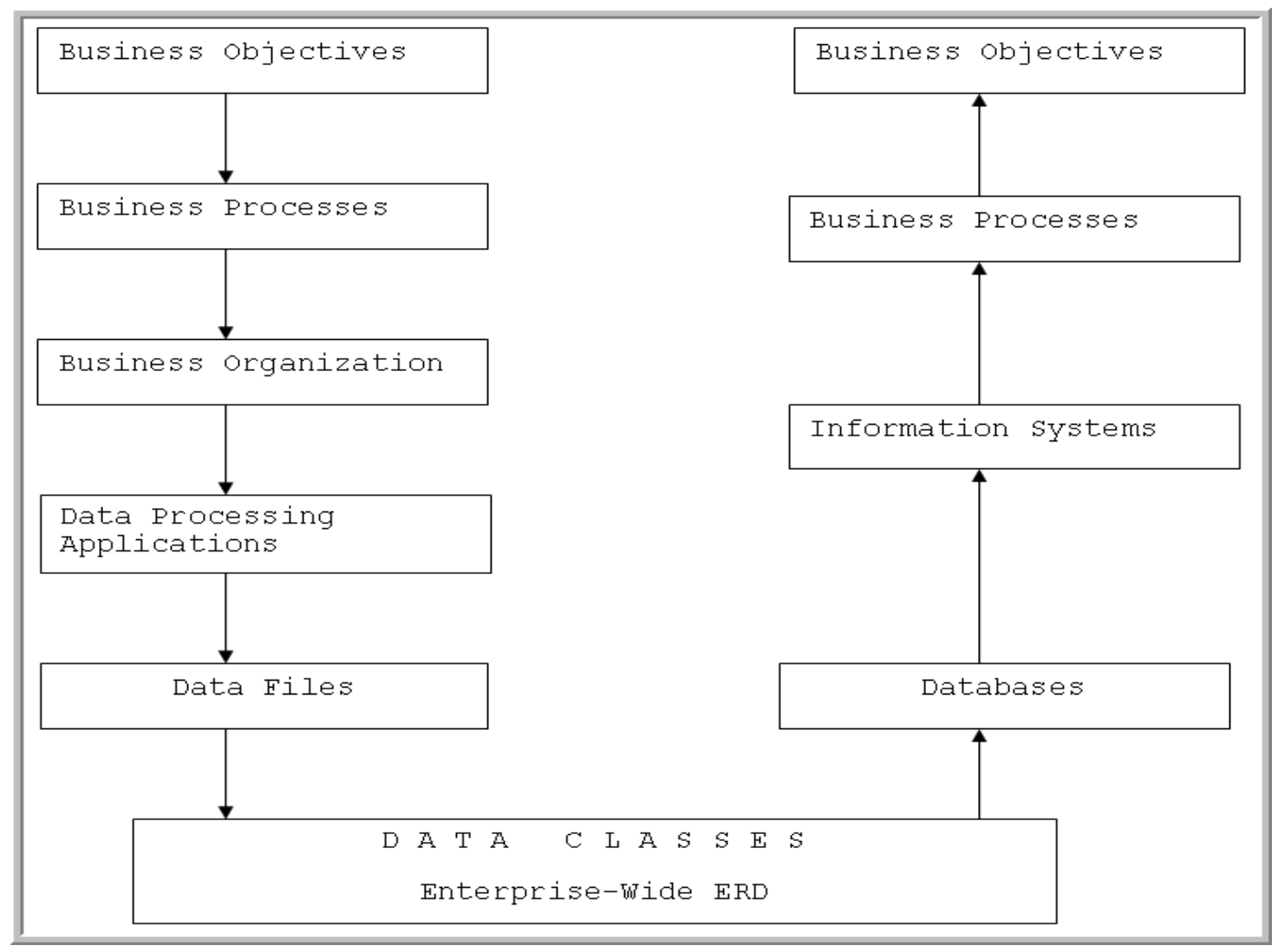

Figure 3. IBM's Business Systems Planning Methodology for IT Planning 
Table 2. Advantages and Limitations of IBM's BSP Methodology for IT Planning

\begin{tabular}{|l|l|}
\hline \multicolumn{1}{|c|}{ Advantages } & \multicolumn{1}{|c|}{ Limitations } \\
\hline Comprehensive and fully proceduralized & Time consuming \\
\hline $\begin{array}{l}\text { Thorough identification of the enterprise's needs using data as } \\
\text { the fundamental corporate resource }\end{array}$ & Expensive to implement \\
\hline Focusing on business processes & $\begin{array}{l}\text { Tends to use information systems to support existing information } \\
\text { flows rather than serving to } \text { re-think them }\end{array}$ \\
\hline Top-down planning with bottom-up implementation & Does not effectively address new opportunities for applying IT \\
\hline
\end{tabular}

\subsection{Critical Success Factors Methodology}

Figure 4 depicts the structured interview process that is the essence of John Rockart's Critical Success Factors methodology for IT planning [19]. By focusing on executive management and their critical success factors, CSF methodology tries to obtain organizational information requirements as perceived by management for planning and control. As such, it provides a reasonably quick path to obtaining consensus on required applications to meet the needs of top management. However, a great deal of detail on application requirements at the transaction processing level where most planning and control data is captured, and the conceptual model of the required enterprise-wide database is left to the implementation stage. Table 3 summarizes the advantages and limitations of CSF methodology $[1,5]$.

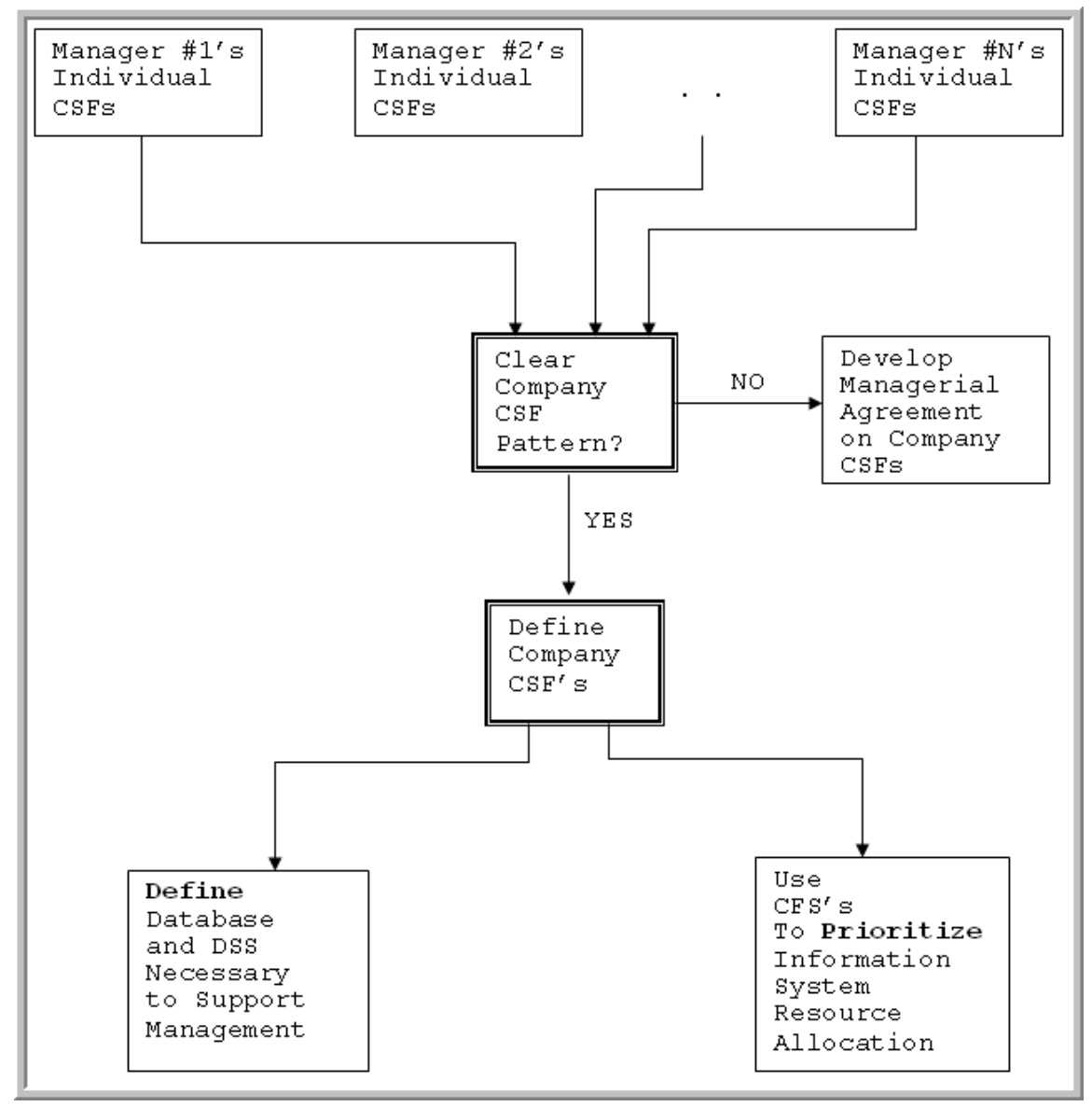

Figure 4. CSF Methodology for IT Planning 
Table 3. Advantages and Limitations of CSF Methodology for IT Planning

\begin{tabular}{|l|l|}
\hline \multicolumn{1}{|c|}{ Advantages } & \multicolumn{1}{c|}{ Limitations } \\
\hline Top management involvement & Emphasizing managerial control needs \\
\hline Addressing right information & $\begin{array}{l}\text { Emphasizing organizational structure and manager-specific needs as opposed } \\
\text { to emphasizing organizational processes independent of individual managers }\end{array}$ \\
\hline Documenting CSFs along with their measures & Not addressing operational requirements in sufficient detail \\
\hline Generating managerial agreement on priorities & \\
\hline Fast & \\
\hline Inexpensive to implement & \\
\hline
\end{tabular}

\subsection{Information Strategy Planning (ISP) Methodology}

James Martin's Information Strategy Planning (ISP) methodology [7, 15, 16], as a part of the overall Information Engineering approach, provides a comprehensive, step-by-step process for developing an organization's MIS Master Plan. It includes the following major steps:

- $\quad$ Linkage Analysis Planning - Develop an overall strategic business vision

- $\quad$ Entity-Relationship Modeling - Map the business functions hierarchically. Associate functions with organizational units, locations, and entities, and document the relationships between the entities that are identified

- Technology Impact Analysis - Map a taxonomy of new technology against the opportunities for new products, services, changes in corporate structure, and so on

- Critical Success Factor Analysis - Identify those areas where "things must go right" if the enterprise is to succeed fully

- Goal and Problem Analysis - Create a structured representation of the goals and problems of the enterprise, associate them with departments, and with the management-by-objectives motivation of individual managers

- Business Area Identification - Revise entity-analysis diagram based on the previous three steps and associate the entities with business functions and place them into a matrix. Cluster the matrix to find naturally cohesive groups of entities and functions

Table 4 summarizes the advantages and limitations of ISP methodology.

Table 4. Advantages and Limitations of ISP Methodology for IT Planning

\begin{tabular}{|l|l|}
\hline \multicolumn{1}{|c|}{ Advantages } & \multicolumn{1}{c|}{ Limitations } \\
\hline Comprehensive and fully Proceduralized & Time consuming \\
\hline Software tools to support the planning process & Expensive to implement \\
\hline Addresses critical success factors & Does not focus adequately on business processes \\
\hline Top-down planning with bottom-up implementation & Does not identify application portfolio with sufficient detail \\
\hline
\end{tabular}

\section{A NeW Methodology For IT PlanNing}

An examination of the different IT planning methodologies leads to a list of desiderata for an effective IT Planning Methodology [13, 14, 22]. These are:

1. Focus on business processes

2. Addressing CSFs

3. Documenting CSFs 
4. Generating managerial agreement on priorities

5. Addressing new IT opportunities

6. Addressing process re-engineering opportunities

7. Addressing MIS policies, objectives, and strategies

8. Identifying TPS requirements

9. Identifying MRS requirements

10. Identifying DSS requirements

11. Conceptual database schema development

12. Subject database schema development

13. Detailed database schema development

14. Top-down planning with bottom up implementation

15. Short time to develop the MIS Master Plan

16. Comprehensive and fully proceduralized

17. Software tools to support the planning process

With the goal of trying to fulfill many of the above desiderata, a new methodology for IT planning based on the Fundamental Business Process Map of the organization is proposed to develop the information architecture to support application portfolio implementation. The new methodology consists of the following five steps:

\section{Step 1. Business Process Analysis and Critical Success Factors}

a) Identify and generate managerial agreement on The Fundamental Business Process Map for the organization.

b) For each fundamental process, identify its customers, purpose, input, and sample output.

c) For each fundamental process, identify and generate managerial agreement on its CSFs along with measurement technique as well as current established goal.

d) Explode each fundamental business process into sub processes to provide an additional level of detail.

e) For each fundamental business process, identify IT opportunities along with the current status of their deployment within the organization.

\section{Step 2. MIS Policies, Objectives, and Strategies}

a) Develop managerial agreement on guidelines for investing in IT by identifying execution risks and measures to control those risks.

\section{Step 3. The Data Integration Infrastructure}

a) Document the world views identified in the hierarchical decomposition of fundamental business processes into sub processes.

b) Develop the entity-relationship data models for each world view.

c) Synthesize the entity-relationship data models into an enterprise-wide conceptual schema.

\section{Step 4. The Application Portfolio and Project Ranking}

a) Document the application systems identified in the hierarchical decomposition of fundamental business processes into sub processes.

b) Develop managerial agreement on the impact of each application system on the fundamental business processes of the organization using the following scale: 


\begin{tabular}{|l|l|}
\hline H - High Impact & $\begin{array}{l}\text { The investment in that application system will have a noticeable payoff in achieving } \\
\text { the critical success factors of that business process. }\end{array}$ \\
\hline M - Medium Impact & \\
\hline L - Low Impact & $\begin{array}{l}\text { The investment in that application system is appropriate for support of that business } \\
\text { process. }\end{array}$ \\
\hline N/A - Not Applicable & For the most part, the application system does not address that business process. \\
\hline
\end{tabular}

\section{Step 5. Execution}

a) The prioritized application systems become the basis of a multi-year system acquisition/development effort.

b) Each system implementation effort would require detailed information requirements analysis which, in turn, provides additional detail for evolving the enterprise-wide conceptual schema.

\section{A COMPARISON AND DIRECTIONS FOR FUTURE RESEARCH}

The proposed new methodology for IT planning has been applied by the author since 1995 for developing the MIS Master Plan for a variety of organizations ranging from a university bookstore to a non-profit human resource development center for the handicapped to the holding company of several manufacturing companies to the ministry of physical education in a country. The methodology has proven to be effective in creating organizational understanding and consensus in where and why to invest in business process re-engineering and information technology. Clearly, wider application and empirical research $[3,4,6,9,21]$ is necessary before any conclusions can be drawn in terms of its advantages for developing an effective MIS Master Plan in shorter duration than ISP or BSP. Notwithstanding that, Table 5 presents a relative comparison of the new methodology vis-à-vis BSP, CSF, and ISP methodologies.

Table 5. A Comparison of IT Planning Methodologies

\begin{tabular}{|c|c|c|c|c|}
\hline Attribute & CSF & BSP & ISP & New Methodology \\
\hline Focus on business processes & $3 *$ & 1 & 2 & 1 \\
\hline Addressing CSFs & 1.5 & 3 & 1.5 & 2 \\
\hline Documenting CSFs & 1 & 3 & 1 & 2 \\
\hline Generating managerial agreement on priorities & 1.5 & 2.5 & 1.5 & 1 \\
\hline Addressing new IT opportunities & 3 & 3 & 1 & 2 \\
\hline Addressing process re-engineering opportunities & 3 & 3 & 2 & 1 \\
\hline Addressing MIS policies, objectives, and strategies & 3 & 2 & 1 & 1 \\
\hline Identifying TPS requirements & 3 & 1 & 1.5 & 2 \\
\hline Identifying MRS requirements & 1 & 2 & 1 & 2 \\
\hline Identifying DSS requirements & 2 & 2 & 1 & 1 \\
\hline Conceptual database schema development & 3 & 1 & 2 & 1.5 \\
\hline Subject database schema development & 3 & 1 & 1 & 3 \\
\hline Detailed database schema development & 3 & 1 & 3 & 2 \\
\hline Top-down planning with bottom-up implementation & 3 & 1 & 1.5 & 2 \\
\hline Time to implement & 1 & 3 & 3 & 1.5 \\
\hline Comprehensive and fully proceduralized & 3 & 1 & 1.5 & 2 \\
\hline Software tools to support the planning process & 3 & 2 & 1 & 3 \\
\hline
\end{tabular}

*1 signifies best, 3 worst

\section{REFERENCES}

1. Ang, J., \& Teo, T.S.H. (1997) "CSFs and Sources of Assistance and Expertise in Strategic IS Planning: a Singapore Perspective.” European Journal of Information Systems, 6(3), pp. 164-171. 
2. Applegate, L.M., McKenney, J.L., \& McFarlan, F.W. (1999) Corporate Information Systems Management: Text and Cases, McGraw-Hill Higher Education.

3. Basu, V., Hartono, E., Lederer, A.L., \& Sethi, V. (2002) "The Impact of Organizational Commitment, Senior Management Involvement, and Team Involvement on Strategic Information Systems Planning." Information and Management, 39(6), pp. 513-524.

4. Benbasat, I., \& Zmud, R. (1999) “Empirical Research in Information Systems: The Practice of Relevance.” MIS Quarterly, 23(1), pp. 3-16.

5. Davis, G.B. (1979) "Comments on the Critical Success Factors Method for Obtaining Management Information Requirements in Article by John F. Rockart." MIS Quarterly, 3(3), pp. 57-58.

6. $\quad$ Earl, M.J. (1993) "Experiences in Strategic Information Systems Planning.” MIS Quarterly, 17(1), pp. 1-24.

7. Finkelstein, C. (1989) An Introduction to Information Engineering. Addison Wesley.

8. Hayward, R.G. (1987) "Developing an Information Systems Strategy." Long Range Planning, 20(2), pp. 100-113.

9. Hirschheim, R., Iivari, J., \& Klein, H.K. (1998) “A Paradigmatic Analysis Contrasting Information Systems Development Approaches And Methodologies.” Information Systems Research, 9(2), pp. 164-193.

10. IBM. (1981) Business Systems Planning: Information Systems Planning Guide.

11. King, W.R. (1978) "Strategic Planning for Management Information Systems.” MIS Quarterly, 2(1), pp. 27-37.

12. Lederer, A.L., \& Gardiner, V. (1992) "Strategic Information Systems Planning: The Method/1 Approach." Information Systems Management, 9(2), pp. 13-20.

13. Lederer, A.L., \& Sethi, V. (1991) "Critical Dimensions of Strategic Information Systems Planning." Decision Sciences, 22(1), pp. 104-119.

14. Lederer, A.L., \& Sethi, V. (1996) "Key Prescriptions for Strategic Information Systems Planning.” Journal of Management Information Systems, 13(1), pp. 35-62.

15. Martin, J. (1982) Strategic Data-Planning Methodologies. Prentice-Hall.

16. Martin, J. (1989) Information Engineering. Prentice Hall.

17. McLean, E.R., \& Soden, J.V. (1977) Strategic Planning for MIS. Wiley-Interscience.

18. Min, S.K., Suh, E.H., \& Kim, S.Y. (1999) "An Integrated Approach Toward Strategic Information Systems Planning." Journal of Strategic Information Systems, 8(4), pp. 373-394.

19. Rockart, J.F. (1979) "Chief Executives Define Their Own Data Needs." Harvard Business Review, 57(2), pp. 81-93.

20. Thompson, S.H.T., \& King, W.R. (1996) "Assessing the impact of integrating business planning and IS planning," Information and Management, 30(6), pp. 309-321.

21. Tukana, S., \& Weber, R. (1996) "An Empirical Test of the Strategic Grid Model of Information Systems Planning.” Decision Sciences, 27(4), pp. 735-765.

22. Ward, J., \& Peppard, J. (2002) Strategic Planning for Information Systems. John Wiley \& Sons.

23. Wetherbe, J.C., Bowman, B., \& Davis, G.B. (1983) “Three Stage Model of MIS Planning." Information and Management, 6(1), pp. 11-25. 
$\underline{\text { NOTES }}$ 